\title{
Right atrial mass - tumor thrombus extension arising from renal cell carcinoma
}

\author{
Jan Dominik', Petr Morávek², Pavel Žáček', Miroslav Brtko'
}

${ }^{1}$ Department of Cardiac Surgery and ${ }^{2}$ Department of Urology, Faculty of Medicine, Charles University Prague, University Hospital Hradec Králové, Czech Republic

Corresponding author: Doc. MUDr. Pavel Žáček, Ph.D., Kardiochirurgická klinika LF UK a FN Hradec Králové, Šimkova 870, 50038 Hradec Králové, e-mail: zacek@fnhk.cz, fax: +4249511953

Renal cell carcinoma (RCC) represents $1-3 \%$ of all malignant visceral tumors. The extension of tumor thrombus into the inferior vena cava occurs in $5-10 \%$ of patients with RCC. Further extension into the right atrium is found only in $1 \%$ of all patients. Diagnosis of renal

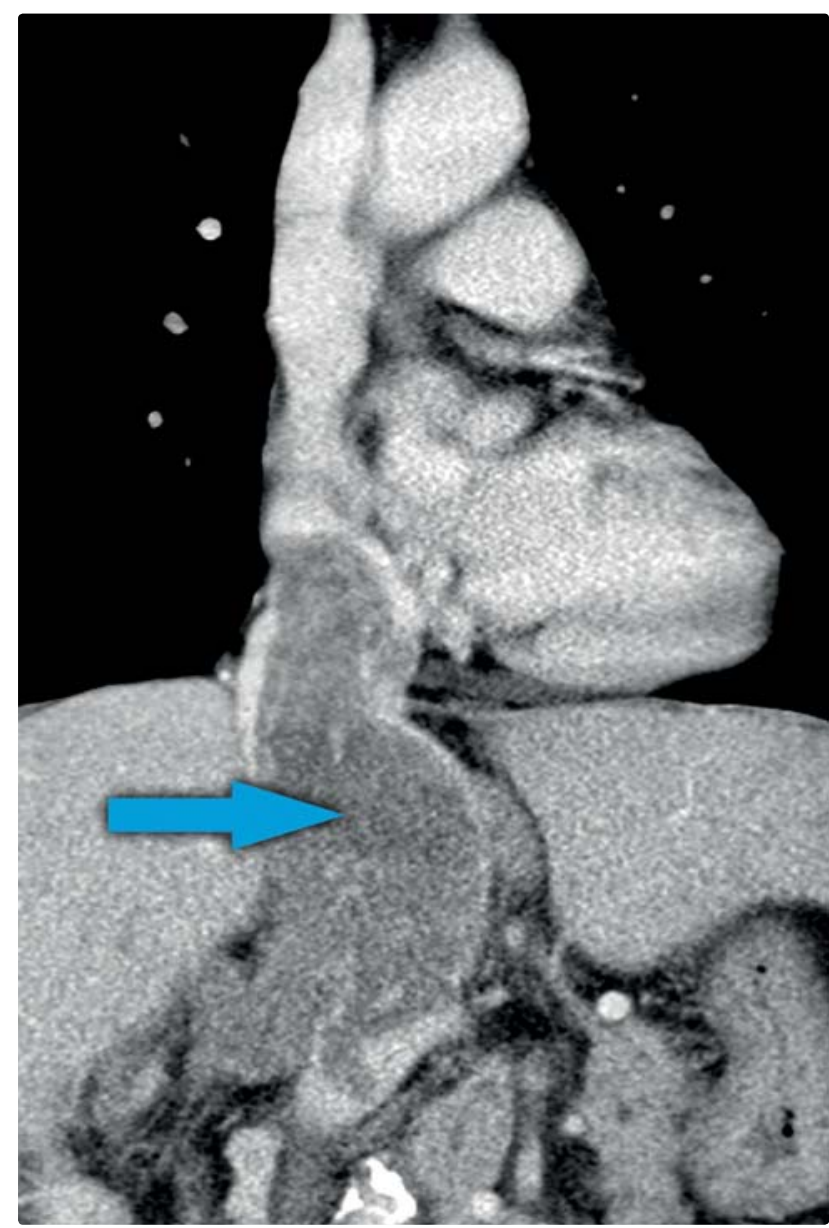

Figure 1 Contrast coronal reconstruction MSCT: obliteration of the inferior vena cava by tumor thrombus protruding into the right atrium (arrow) tumor and his intravascular invasion is done by computed tomography (CT) or magnetic resonance imaging (MRI).

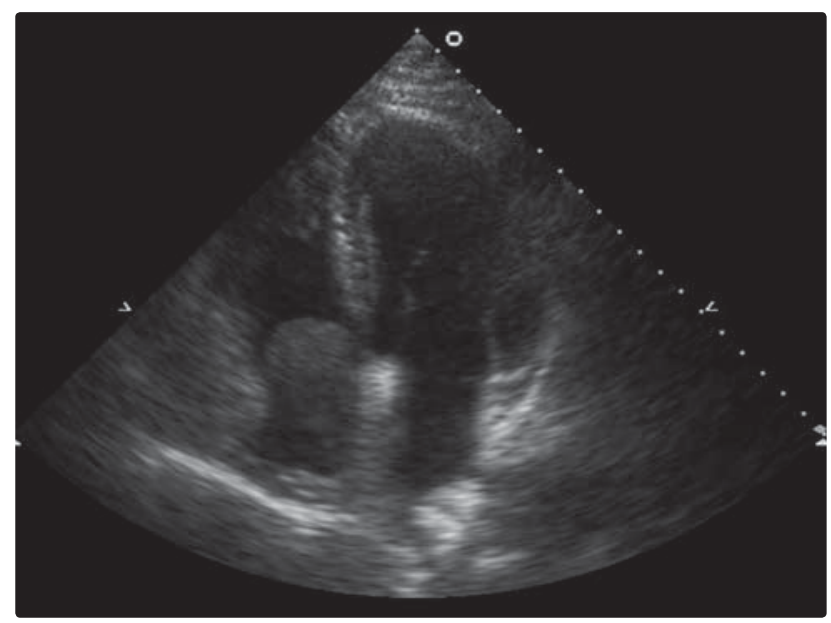

Figure 2 TTE - apical four-chamber view: tumor thrombus $56 \times 25 \mathrm{~mm}$ fills almost completely the right atrium

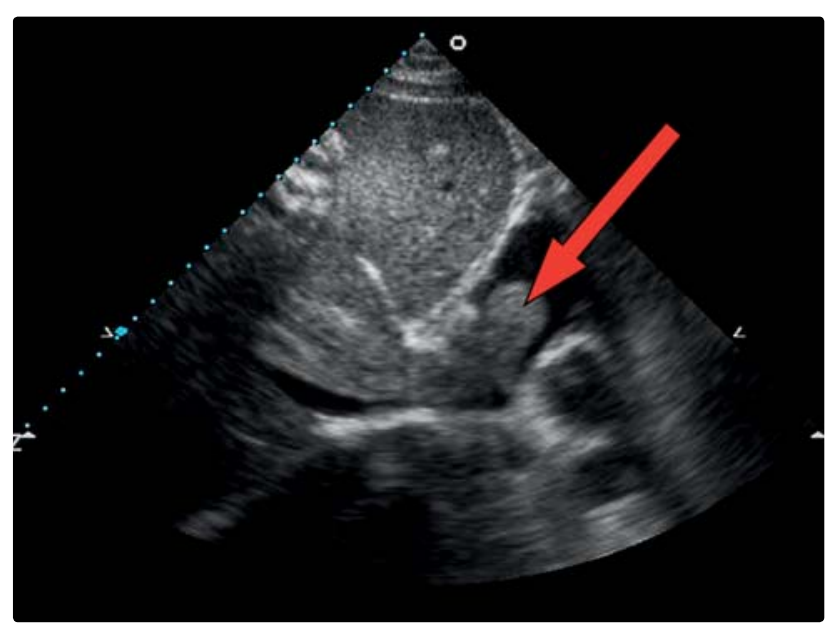

Figure 3 TTE - subcostal view: the inferior vena cava is dilated and almost completely obliterated by dumbbell-shaped thrombus, which extends into the right atrium (arrow) 


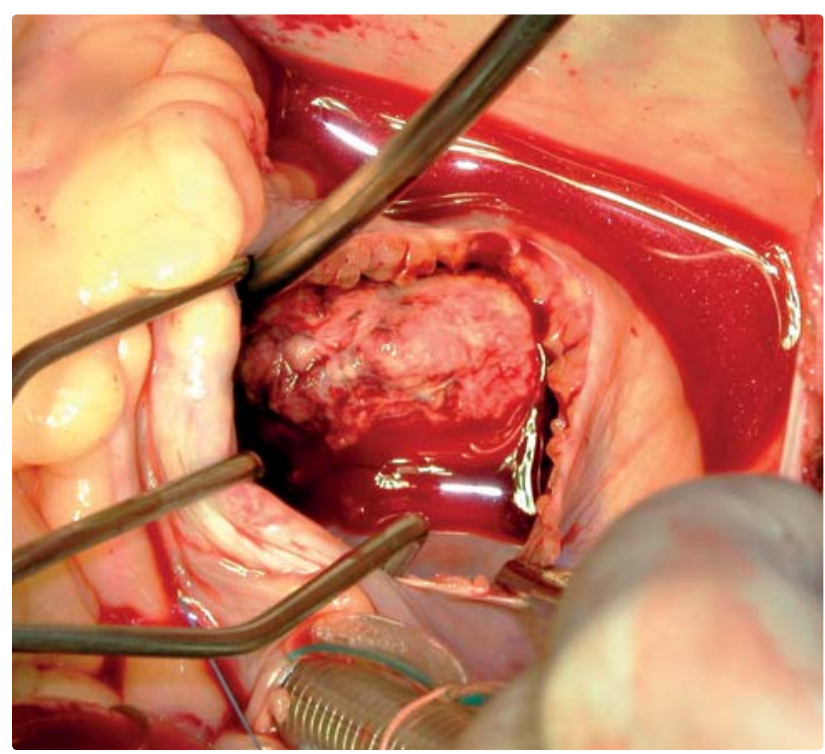

Figure 4 Exposure of the tumor mass after right atriotomy

Precise information about tumor invasion into the right atrium and its localization is obtained by transthoracic echocardiography (TTE). Radical nephrectomy with tumorthrombus extraction with use of cardiopulmonary bypass in deep hypothermia and circulatory arrest seems to be optimal procedure in view of radicality and safety.

A right kidney tumor with intravascular invasion of tumor thrombus was diagnosed on CT in a 54-year-old man (Figure 1). TTE confirmed extension of the tumor thrombus into the right atrium (Figures 2 and 3). Pulmonary, brain and bone metastases were excluded by CT and bone scintigraphy. Preoperative coronary angiography revealed significant stenosis of the left anterior descending (LAD) and the right coronary artery (RCA). Radical right-sided nephrectomy was performed and tumor thrombectomy from inferior vena cava and right atrium was carried out using cardiopulmonary bypass with hypothermic circulatory arrest (Figures 4 and 5). Peripheral anastomoses of aortocoronary bypasses to LAD and RCA were performed during cooling and central anastomoses to ascending aorta during rewarming of the patient. Postoperative course was

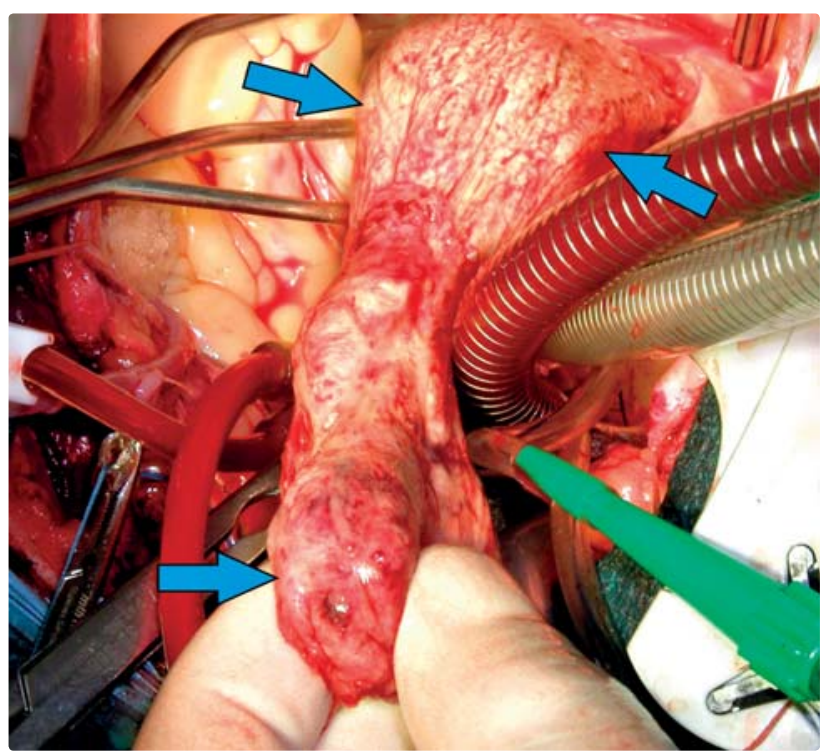

Figure 5 Extraction of the tumor thrombus from the right atrium and the inferior vena cava (arrows)

uneventful and patient is asymptomatic one year after operation.

\section{References}

1. Lonský $\mathrm{V}$, Dominik J, Morávek $\mathrm{P}$, et al. Mimotělní oběh $s$ hypotermií při operaci Grawitzova nádoru širíííino se do dolní duté žily a pravé předsíně srdeční. Cor Vasa 1997;39:241-243.

2. Chiappini B, Savini C, Marinelli G, et al. Cavoatrial tumor thrombus: single-stage surgical approach with profound hypothermia and circulatory arrest, including a review of the literature. J Thorac Cardiovasc Surg 2002;124:684-688.

3. Morávek P, Dominik J. Radikale Operation bei Nirerenkarzinom mit Tumorthombose im rechten Herzvorhof. J Urol Urogynäkol 2002;9(4):20-25.

4. Rannikko A, Sipponen J, Nordling S, Ruutu M. Cavoatrial extension of renal cell cancer: results of operative treatment in Helsinki University Hospital between 1990 and 2000. Scand J Surg 2004;93:213-216.

5. Schimmer $\mathrm{C}$, Hillig F, Riedmiller $\mathrm{H}$, Elert $\mathrm{O}$. Surgical treatment of renal cell carcinoma with intravascular extension. Interact Cardiovasc Thorac Surg 2004;3:395-397.

6. Kalkat MS, Abedin A, Rooney $S$, et al. Renal tumours with cavo-atrial extension: surgical management and outcome. Interact Cardiovasc Thorac Surg 2008;7:981-985.

Došlo do redakce: 8. 3. 2011

Prijato: 22. 5. 2011 